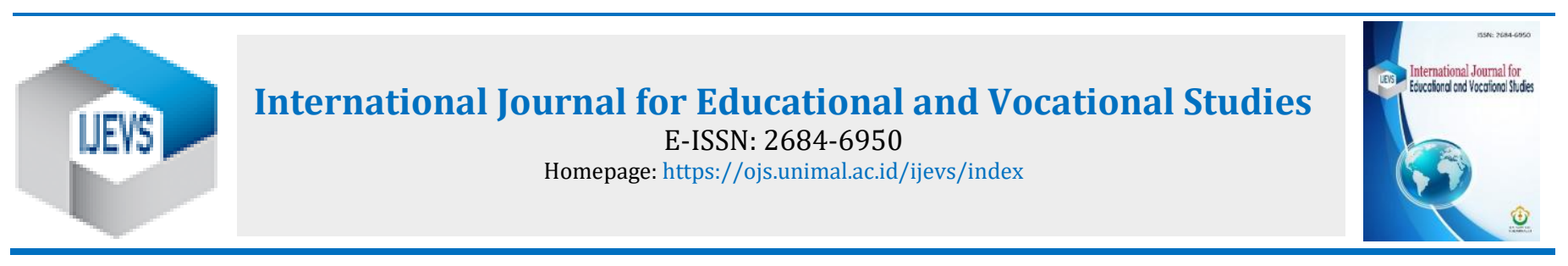

\title{
Implementation of distance history learning during the Pandemic Covid-19
}

\author{
Wulan Nurjanah* Akhmad Arif Musadad, \& Hieronymus Purwanta \\ Magister of History Education, Sebelas Maret University, Surakarta, Indonesia \\ wulannurjanah@student.uns.ac.id; arif_mussadad_fkip@yahoo.co.id; purwantah@gmail.com \\ *Corresponding Author: wulannurjanah@student.uns.ac.id | Phone Number: +628568133633
}

\section{ARTICLE INFO}

Received: 16-05-2021

Received in revised: 28-06-2021

Accepted: $29-07-2021$

Available online: $30-8-2021$

\section{KEYWORDS}

History learning;

Distance learning;

Covid-19 pandemic;

\begin{abstract}
A B S T R A C T
The Covid-19 pandemic has an impact on all aspects of life including education, hence, the government issued a study from home policy. The Ministry of Education and Culture issued a Circular Letter Number 4 of 2020 concerning the Implementation of the Education Policy for the Emergency Period of the Spread of Covid-19 conveyed that the learning process takes place remotely or learn from home. This policy was issued as an effort to reduce the spread of the virus. This is a challenge and opportunity for the world of education nowadays. Distance learning is carried out online by utilizing technology, information, and communication. The implementation of distance history learning by utilizing technology is very helpful for school on teaching and learning process, but in its progress encountered various obstacles. Facilities and infrastructure that are not adequate, the lack of readiness of teachers and students, as well as the unstable condition of the internet network is a challenge that is often encountered. Therefore, this article seeks to provide an overview of the implementation of distance learning far done during the Covid-19 pandemic. The research was conducted using a descriptive approach qualitative. The object of research was carried out on the history learning process carried out at SMA Negeri 15 Pandeglang which is located at Jalan Raya Carita KM. 05 Labuan, Banjarmasin, Carita, Pandeglang, Banten. Data obtained through primary and secondary sources and researchers as the main instrument. Technique Data collection was done by interview, observation, and document analysis. Researchers use techniques triangulation of sources and methods and analyzed with an interactive model as a data analysis technique. Data obtained through interviews, observation, and document analysis.
\end{abstract}

\section{INTRODUCTION}

At the end of 2019, a coronavirus appeared in Wuhan, China and spread throughout the world (Lee, 2020). Based on WHO data within one year, $122,524,424$ positive cases were recorded in 223 countries. While in Indonesia from early March 2020 to March 23, 2021, there were 1,460,184 positive cases and 39,550 passed away (Satuan Tugas Penanganan COVID-19, 2021). Therefore, WHO announced the status global pandemic for the whole world. The impact of the Covid-19 pandemic affects all the orders of human life. Various countries have implemented policies to prevent the spread of the virus Covid-19. Indonesia also issued several regulations to suppress the spread of the virus, namely impose a policy of limiting community activities or social distancing. This policy is of course affecting all fields, including the field of education.
The conditions of the Covid-19 pandemic have encouraged various parties to create a safe learning system. Distance learning is becoming an effort during a pandemic so that in many countries it is almost simultaneously implementing this system (Dai \& Lin, 2020; Grammes, 2020; Hoq, 2020; Sun et al., 2020; Zhu \& Liu, 2020). Distance learning uses the internet as the main support so that learning is carried out online (Bao, 2020; Basilaia \& Kvavadze, 2020). Learning takes place by making use of technology so that the condition of students, both physical, mental, spiritual, and intellectual health remains awake (Goldschmidt, 2020). 


\section{LITERATURE REVIEW}

\section{Coronavirus Disease (Covid-19)}

The Covid-19 pandemic has been going on for more than a year and is still a threat to the world (Fauci et al., 2020). The pandemic was caused by the SARS-Cov-2 virus with the disease being called Coronavirus Disease 2019 or known as Covid-19. This virus first appeared in Wuhan, China. The SARS-CoV-2 virus is zoonotic so there is a possibility that the virus originated from animals and was transmitted to humans (Velavan \& Meyer, 2020). Subsequent developments indicate that transmission occurs between humans (humans to human), which is predicted through droplets. This is consistent with the incidence of transmission to officer's health care provider for a Covid-19 patient, accompanied by other evidence of transmission outside of China from an attendee from the city of Shanghai, China to Germany and accompanied by the discovery of positive results in people met in office. In this case, it is even said that the infection occurred when the index case had not yet experienced its symptoms (asymptomatic) or still in the incubation period. This transmission occurs mainly through droplets and contact with the virus then the virus can enter into the open mucosa. A tried analysis measures the rate of transmission based on the incubation period, symptoms and duration between symptoms with patients who are isolated (Handayani et al., 2020).

\section{History Learning}

History is the Tarikh of the word arkh which means the recording of a certain event and at a certain time (Hamid \& Madjid, 2011). According to Kuntowijoyo, (2005) history is a reconstruction of the past. While according to the Ministry of National Education, (2003) history is a subject that can impart knowledge and values regarding the process of change and development of Indonesian society and the world that have occurred past to present. Sapriya (2012) explains that history learning is a branch of science from time to time knowledge that examines the origin and development and role of society at that time past that contains wisdom values that can be used to train intelligence, shape attitudes, character and personality of students.

History learning has a function to build students' awareness of the change process and the development of society and building a mindset and historical awareness to find, understand and explain the identity of the nation and the values of life in the past, present, and future (Agung S \& Wahyuni, 2013). Therefore, history is included in the subjects at school. At the primary and junior high school levels, history is part of the social studies subject, while at higher education and vocational levels, history becomes a separate subject.

\section{Distance Learning during the Covid-19 Pandemic}

Distance learning is a learning process that is carried out indirectly, namely teachers and students are in different places by making use of technology (Buselic, 2012). Utilization technology is the focus of distance learning systems (Darmawan, 2016). Therefore, Distance learning emphasizes technology-assisted learning methods to assist teachers in delivering material to students who do not meet in person.

Distance learning develops an electronic-based learning model with internet media as the main supporter (Darmawan, 2016). Therefore, this learning system is referred to as online learning (online). Online learning is supported by electronic media such as telephone, radios, computers, laptops, or gadgets and application devices that produce audio, video, images, and text (Basilaia \& Kvavadze, 2020; Darmawan, 2014; Latip, 2020; Suryani, 2016). Application device supports free online learning, namely whatsapp, google meet, zoom meeting, google classroom, Webex, and LMS learning device systems such as e-learning moddle (Chick et al., 2020; Herliandry et al., 2020; Marharjono, 2020; Pakpahan \& Fitriani, 2020; Sumarno, 2020; Utami, 2020).

Distance learning during the Covid-19 pandemic according to Huang et al., (2020) is learning which is implemented with the Flexible Learning system, namely a learning system that is implemented at any time and anywhere; students can learn whatever they want; learning resources can be obtained from anywhere, both from teachers and media such as the web; teachers can have various opportunities in determining learning methods, such as tutoring, independent study, seminars, debates, and online discussions; and implementation of learning evaluations can use a system of more flexibility for students in reported activities during the Covid-19 pandemic.

According to Cheawjindakarn et al., (2012) states that there are five determining factors in the success of distance learning, namely a) Management of the institution. This factor has to do with design planning and implementing distance learning. The learning design is designed by the central institution concerned and the school as implementers in the field. Distance learning success will be materialized if there is an appropriate direction and curriculum and support from the central institution to the party's implementers in the field; b) Learning environment. Learning environmental factors in distance learning relating to the location of learning, the ability of students and teachers to access the internet and technology, and online systems. This factor is crucial because the internet is the main asset distance learning; c) Learning design. Learning design is an important part of learning. 
This distance learning method is something new for teachers and students so that the learning design that is designed must be as good as possible. Learning objectives, content learning, learning strategies, learning psychology, and learning assessment should adjusting to the conditions of the Covid-19 pandemic; d) Support services. This support service consists of training and communication tools. Schools should conduct training for teachers and students on distance learning. The purpose of this training is to improve the abilities of teachers and students in using communication tools and technology that become media for distance learning, and e) Evaluation learning. Learning evaluation is a major part of learning because it is to measures the level of attainment of the learning process. Thus, the evaluation of learning under any conditions must continue to be implemented, including during the Covid-19 pandemic. However, the evaluation of learning, both summative and formative during a pandemic are carried out more flexibly. The flexibility of the assessment including from its assessment methods, such as presentations, research papers, peer assessments, and eportfolio. Besides, the assessment can be carried out using the online test method, namely using various test platforms or applications, such as quizziz, Kahoot, and google forms.

\section{METHODS}

This research use desciptive qualitative approach. This method is used to analyze an event, phenomenon, or social situation holistically and then describe it in the form of words and language with context and scientific methods (Moleong, 2019). The object of this research is the history learning process which is carried out at SMA Negeri 15 Pandeglang which is located at Jalan Raya Carita KM. 05 Labuan, Banjarmasin Village, Carita District, Pandeglang, Banten. Data obtained through primary and secondary sources and researchers as the main instrument. Data collection techniques were carried out by interview, observation, and document analysis. The researcher used source and method triangulation technique and analyzed with interactive model as a data analysis technique. Data obtained through interviews, observation, and document analysis.

\section{RESULTS AND DISCUSSIONS}

Since the issuance of Circular Letter No. 4 of 2020 concerning distance learning policy, the Indonesian government closed all schools from elementary to college. Learning activities are carried out from home using learning guidelines that have been prepared by the government. That matter is an effort to prevent the spread of the Covid-19 virus.
SMA Negeri 15 Pandeglang implemented learning from home as a follow-up to its policy implemented by the central and local governments. Learning from home has been implemented since March 2020. The learning method is done remotely with an online system. Distance learning makes use of technology information and communication as well as applications, namely whatsapp, google meet, and google classroom.

The results of observations and research interviews on history learning are obtained online are done using whatsapp and google meet. The teacher explains the material and gives assignments via whatsapp and google classroom. While filling in the student attendance list was through google meet. The whatsapp and google classroom applications are used more often because they are easier and not spend a lot of internet quota.

The implementation of distance learning history starts from the planning, implementation, and evaluation process. In the lesson planning process, the teacher prepares a lesson plan (RPP) which is specifically used during a pandemic, which consists of only one sheet. The lesson plan specifically for pandemic generally is the same as the RPP before the pandemic, but what differentiates is the basic competencies use is chosen to be substantive and one hour of lessons is only 30 minutes. In the implementation of the learning process, the teacher practices the learning contained in the lesson plan, namely the implementation of learning using learning methods with selected media and applications. As for learning media used in history learning is use WhatsApp in explaining the material while giving assignments using google classroom. In the learning evaluation process, teachers use several forms, such as assignments and tests. The teacher assigns by instructing students to make a summary of the material and provide a written test through google classroom.

The distance history learning process has been carried out, but there are still obstacles to be encountered. During the learning process, the number of student attendance has not reached $100 \%$. This is because there are still students who do not have a smartphone and internet quota. Schools have tried to overcome these obstacles, namely by providing internet quota assistance which is also supported by the government, and students who are not having a smartphone are asked to come to school to use school facilities. According to students, $10 \mathrm{~GB}$ of internet quota assistance from the government has helped, but not maximally. That matter because the quota given cannot be used by all applications and the quota runs out quickly because it is not only one subject is used.

The following is the history learning process that took place during the Covid-19 pandemic at SMA Negeri 15 Pandeglang. 


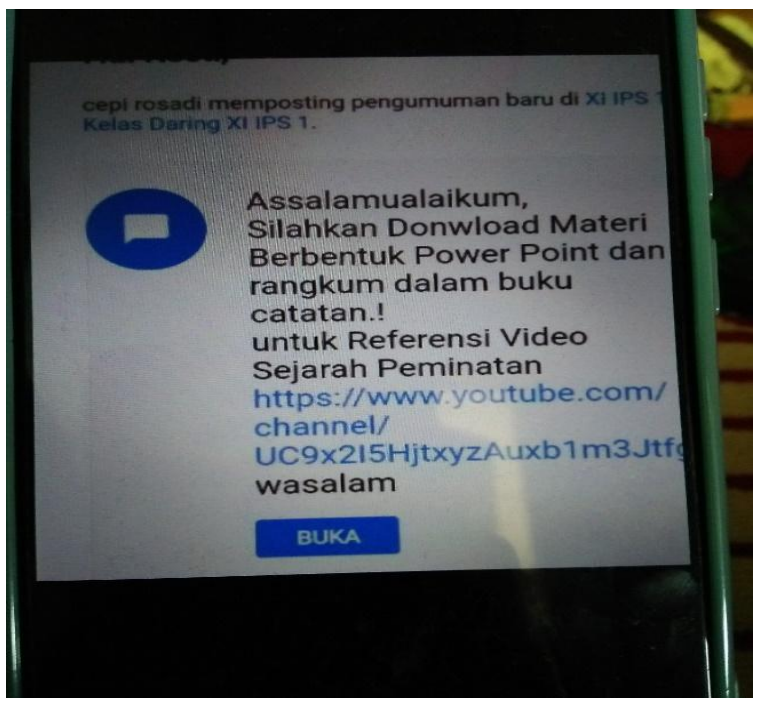

Figure 1. History learning of XI IPS 1

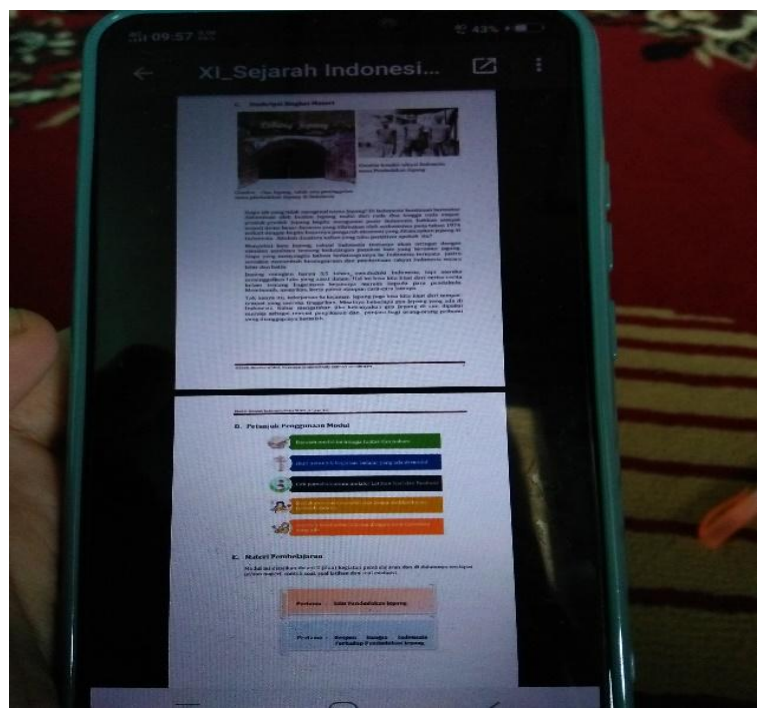

Figure 2. E-module of History Subject

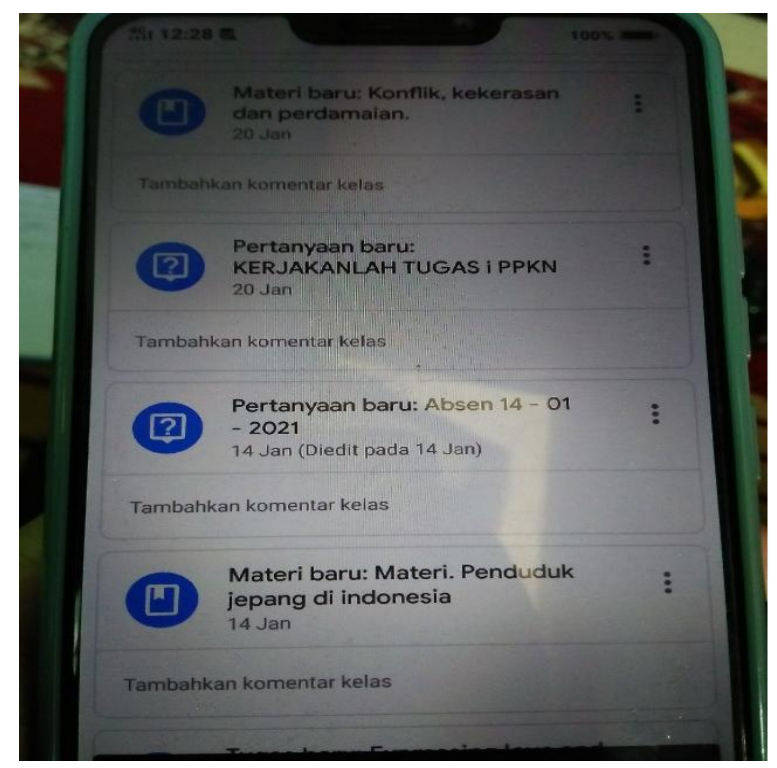

Figure 3. Smartphone learning media

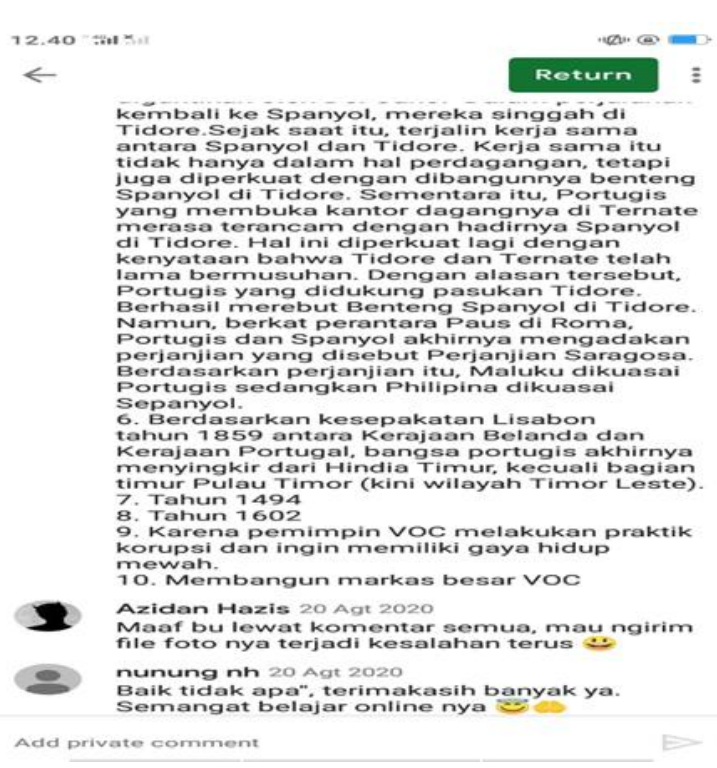

Figure 4. Test through google classroom

\section{CONCLUSIONS}

The Covid-19 pandemic is both a challenge and a threat to various parties in the world, one of them in Indonesia. All aspects of life are affected including aspects of education. The learning process during Covid-19 pandemic is changing, namely using a distance learning process as an effort to suppress spread of the virus. Learning takes place using several applications that are supported by technology and the internet. Distance learning has become a new thing in Indonesian education so that at there are still obstacles in its implementation. Therefore, it still needs evaluation by various parties so that the learning process takes place optimally and learning objectives can be achieved even during a pandemic.

\section{Acknowledgement}

The authors would like to thank the supervising lecturer from the History Education Program, Postgraduate School of Universitas Sebelas Maret and history teacher at SMAN 15 Pandeglang for their assistance in completing this research.

\section{Author's Contributions}

The authors coordinates and has discussions in drafting the concepts and results from the beginning of the manuscript to the end. All authors approved the manuscript.

\section{Conflict of Interest}

The authors claim that they have no competing interests.

\section{REFERENCES}

Agung S, L., \& Wahyuni, S. (2013). Perencanaan Pembelajaran Sejarah. Yogyakarta: Penerbit Ombak.

Bao, W. (2020). COVID -19 and online teaching in higher education: A case study of Peking University . Human 
Behavior and Emerging Technologies, 2(2), 113-115.

https://doi.org/10.1002/hbe2.191

Basilaia, G., \& Kvavadze, D. (2020). Transition to Online Education in Schools during a SARS-CoV-2 Coronavirus (COVID-19)

Pandemic in Georgia. Pedagogical Research, 5(4).

https://doi.org/10.29333/pr/7937

Buselic, M. (2012). Distance Learning - concepts and contributions. Oeconomica Jadertina, 1, 23-34.

Cheawjindakarn, B., Suwannatthachote, P., \& Theeraroungchaisri, A. (2012). Critical Success Factors for Online Distance Learning in Higher Education: A Review of the Literature. Creative Education, 03(08), 61-66.

https://doi.org/10.4236/ce.2012.38b014

Chick, R. C., Clifton, G. T., Peace, K. M., Propper, B. W., Hale, D. F., Alseidi, A. A., \& Vreeland, T. J. (2020). Using Technology to Maintain the Education of Residents During the COVID-19 Pandemic. Journal of Surgical Education, 77(4), 729-732. https://doi.org/10.1016/j.jsurg.2020.03.018

Dai, D., \& Lin, G. (2020). Online Home Study Plan for Postponed 2020 Spring Semester during the COVID-19 Epidemic: A Case Study of Tangquan Middle School in Nanjing, Jiangsu Province, China. SSRN Electronic Journal. https://doi.org/10.2139/ssrn.3555539

Darmawan, D. (2014). Inovasi Pendidikan: Pendekatan Praktik Teknologi Multimedia dan Pembelajaran Online. Bandung: PT Remaja Rosdakarya.

Darmawan, D. (2016). Pengembangan E-Learning Teori dan Desain. Bandung: PT. Remaja Rosdakarya.

Depdiknas. (2003). Pedoman Khusus Pengembangan Silabus dan Penilaian Mata Pelajaran Sejarah. Jakarta : PT. Cipta Adi Pustaka.

Fauci, A. S., Lane, H. C., \& Redfield, R. R. (2020). Covid-19 Navigating the Uncharted. New England Journal of Medicine, 382(13), 1268-1269.

https://doi.org/10.1056/nejme2002387

Goldschmidt, K. (2020). The COVID-19 Pandemic: Technology use to Support the Wellbeing of Children Karen. Journal of Pediatric Nursing, 53, 88-90.

https://doi.org/http://doi.org./10.1016/j.pedn.2020.04.013

Grammes, T. (2020). Covid-19 pandemic, emergency remote teaching and social science education. Journal of Social Science Education, 19 (Special Issue), 1-7. https://doi.org/10.4119/jsse-3544

Hamid, A. R., \& Madjid, M. S. (2011). Pengantar Ilmu Sejarah. Yogyakarta: Ombak.

Handayani, D., Hadi, D. R., Isbaniah, F., Burhan, E., \& Agustin, H. (2020). Penyakit Virus Corona 2019. Jurnal Respirologi Indonesia, 40(2), 119-129.

Herliandry, L. D., Nurhasanah, Suban, M. E., \& Heru, K. (2020). Pembelajaran Pada Masa Pandemi Covid-19. Jurnal Teknologi Pendidikan, 22(1), 65-70.

https://doi.org/https://doi.org/10. 21009/jtp.v22i1.15286

Hoq, M. Z. (2020). E-Learning During the Period of Pandemic ( COVID-19) in the Kingdom of Saudi Arabia : An Empirical Study. American Journal of Educational Research, 8(7), 457-464. https://doi.org/10.12691/education-8-7-2
Huang, R. H., Liu, D. J., Tlili, A., Yang, J. F., \& Wang, H. H. (2020). Handbook on facilitating flexible learning during educational disruption: The Chinese experience in maintaining undisrupted learning in COVID-19 Outbreak. Smart Learning Institute of Beijing Normal University UNESCO, 1-54. https://iite.unesco.org/news/handbook-onfacilitating-flexible-learning-during-educational-disruption/

Kuntowijoyo. (2005). Pengantar Ilmu Sejarah. Yogyakarta: Tiara Wacana.

Latip, A. (2020). Peran Literasi Teknologi Informasi Dan Komunikasi Pada Pembelajaran Jarak Jauh Di Masa Pandemi Covid-19. EduTeach : Jurnal Edukasi Dan Teknologi Pembelajaran, 1(2), 108-116. https://doi.org/10.37859/eduteach.v1i2.1956

Lee, A. (2020). Wuhan novel coronavirus (COVID-19): why global control is challenging? Public Health, January, 19-21. https://doi.org/doi: 10.1016/j.puhe.2020.02.001

Marharjono. (2020). Manfaat Pembelajaran Sejarah Menggunakan Google Classroom Pada Masa Pandemi Covid-19. Jurnal Karya Ilmiah Guru, 5(1), 56-63. https://jurnaldikpora.jogjaprov.go.id/index.php/jurnalideguru/article/downlo $\mathrm{ad} / 155 / 176$

Moleong, L. J. (2019). Metodologi Penelitian Kualitatif Edisi Revisi. Bandung: PT Remaja Rosdakarya.

Pakpahan, R., \& Fitriani, Y. (2020). Analisa Pemanfaatan Teknologi Informasi Dalam Pembelajaran Jarak Jauh Di Tengah Pandemi Virus Corona Covid-19 Roida. JISAMAR (Journal of Information System, Applied, Management, Accounting and Researh), 4(2), 30-36.

Sapriya. (2012). Pendidikan IPS: Konsep dan Pembelajaran. PT. Remaja Rosdakarya.

Satuan Tugas Penanganan COVID-19. (2021). Data Sebaran. https://covid19.go.id/

Sumarno. (2020). Adaptasi Sekolah dalam Mengimplementasikan Pembelajaran Jarak Jauh pada Masa Pandemi COVID-19 (Studi Kasus SMP Muhammadiyah Karanggeneng Kabupaten Lamongan). Jurnal Tarbiyah \& Ilmu Keguruan (JTIK) Borneo, 1(2), 149-162.

Sun, Li., Tang, Y., \& Zuo, W. (2020). Coronavirus pushes education online. Nature Materials, 19(June), 687.

Suryani, N. (2016). Pengembangan Media Pembelajaran Sejarah Berbasis IT. Sejarah Dan Budaya : Jurnal Sejarah, Budaya, Dan Pengajarannya, 10(2), 186-196. https://doi.org/10.17977/um020v10i22016p186

Utami, I. W. P. (2020). Pemanfaatan Digital History Untuk Pembelajaran Sejarah Lokal. Jurnal Pendidikan Sejarah Indonesia, 3(1), 52-62.

http://journal2.um.ac.id/index.php/sejarah/article/view/13944

Velavan, T. P., \& Meyer, C. G. (2020). The COVID-19 epidemic. Tropical Medicine and International Health, 25(3), 278280. https://doi.org/10.1111/tmi.13383

Zhu, X., \& Liu, J. (2020). Education in and After Covid-19: Immediate Responses and Long-Term Visions. Postdigital Science and Education, 2(3), 695-699. https://doi.org/10.1007/s42438-020-00126-3 